\title{
X-Ray Photoelectron Spectroscopy for industrial applications
}

Kormunda Martin, Univerzita J. E. Purkyne, Ceske mladeze 6, 40096 Usti nad Labem. E-mail: martin.kormunda@ujep.cz

The X-Ray Photoelectron Spectroscopy is versatile technique based on high energy photon stimulation. The investigated areas of the sample are about the top $10 \mathrm{~nm}$. The basic composition and chemical bonds can be evaluated. The XPS can be used in the quality control, ageing studies and many more. Samples of CoSbY alloy, carbon-rich coatings and films with tin were investigated here.. The importance of proper handle on carbon contaminations on CoSbY alloy is illustrated. The chemical shift of carbon $\mathrm{C}$ 1s peak and oxidation state tin Sn $3 d$ photo electron peaks are presented.

Keywords: XPS, ESCA, surface analyses

\section{References}

[1] LAHUCKÝ, D., MAGA, D., LIPTÁK, P., Zlepšení tribologických parametru chemicko-tepelnou úpravou povrchu. In Strojírenská technologie XII, 2007, sv. 3, s. 29-33. ISSN 1211-4162.

[2] BRIGGS, D., GRANT, J. T. Surface analysis by Auger and X-ray photoelectron spectroscopy. IM Publications and Surface Spectra Limited, 2003. s. 899. ISBN 1-901019-04-7.

[3] KORMUNDA, M., PAVLIK, J. Characterization of oxygen and argon ion flux interaction with PET surfaces by insitu XPS and ex-situ FTIR. Polymer Degradation and Stability, 2010, sv. 95, s. 1783 - 1788.

[4] CRIST, V. B. Handbook of The Elements and Native Oxides. XPS International. 1999.

[5] MATOUSEK, J., PAVlíK, J., STRÝHAL, Z., PIPPIG, F., KOVACÍK, L., STARÝ V. Properties of tin/plasma polymer nanocomposites. Vacuum, 2009, sv. 84, s. 86-89.

[6] REBROVÁ, S., PEŠLOVÁ, F., HAJDUCHOVÁ, L., KRMELA, J.. Degradácia povrchov sklárskych foriem. In Strojírenská technologie X, 2005, sv. 3, s. 8-11. ISSN 1211-4162.

Reviews:

Prof. Iva Nová, MSc., Ph.D. Prof. Ivan Lukáč, MSc., PhD. 